\title{
REFINED TAXON SAMPLING DISCLOSES NEW QUINONE PATTERNS AND Relationships among Sundews (Drosera, Droseraceae)
}

In Memoriam Allen James Lowrie (1948 - 2021), without whom we would not even know about many species investigated in this study

JAN SCHLAUER • Zwischenstr. 11 • D-60594 Frankfurt/Main•Germany • jan@carnivorousplants.org Andreas FleischmanN • Botanische Staatssammlung München • Menzinger Str. 67 • D-80638 Munich•Germany・fleischmann@bio.lmu.de

Keywords: Drosera, phytochemistry, naphthoquinones, chemotaxonomy.

Abstract: In a screening of 43 accessions of predominantly Australian sundew species (Drosera), naphthoquinones were detected convincingly for the first time in D. section Lasiocephala (D. petiolaris group, or 'wooly sundews'), where these metabolites remain restricted to a minority of four closely related species. Great chemical similarity across the large geographic range confirms a close phylogenetic affinity between taxa of the D. peltata species group (of D. section Ergaleium, from tropical and Eastern Asia to New Zealand). Drosera barrettiorum (D. section Arachnopus) is chemically confirmed as a close relative of $D$. hartmeyerorum. The recently described species $D$. margaritacea in the same section is chemically different from the morphologically close D. finlaysoniana. Quinone data for African and South American sundews (D. sections Drosera, Ptycnostigma and Brasilianae) shed further light on the affinities between these taxonomically challenging plants.

\section{Introduction}

The Drosera petiolaris R.Br. group (D. section Lasiocephala Planch.) of tropical Australasia is the last remaining speciose section in the genus Drosera L. that has hitherto resisted to yield appreciable amounts of naphthoquinones, although traces of plumbagin $(\mathbf{P})$ have been detected in $D$. banksii R.Br. ex DC. (Schlauer et al. 2019a). Many closely interrelated taxa have been described recently (Gibson et al. 2012; de Salas 2018) in the polymorphic and widespread D. peltata Thunb. group (D. section Ergaleium Planch., from tropical and Eastern Asia to New Zealand), and an attempt is made here to test and compare the chemical profiles of as many of these segregates as possible. Drosera section Arachnopus Planch. has already been screened for naphthoquinones to some extent but $D$. barrettiorum Lowrie that is supposedly closely related to D. hartmeyerorum Schlauer, and D. margaritacea Krueger \& A.Fleischm. that is morphologically similar to D. finlaysoniana Wall. ex Arn., have not been at our disposal for chemical investigation before. Similar comparisons are also due for a number of additional pairs of sister taxa from Australia, Africa, and America, of which cultivated material has now become available.

Materials and methods

All plants used in the present study were cultivated at Andreas Fleischmann's greenhouse in southern Germany. Fresh leaf samples were investigated as reported previously (Schlauer et al. 2017). 
Naphthoquinones were detected in the investigated samples as summarized (together with previous results) in Table 1.

\begin{tabular}{|c|c|c|c|}
\hline Section & Taxon & Quinone(s) & Comment \\
\hline Lasiocephala & D. brevicornis & 0 & new data \\
\hline Lasiocephala & D. broomensis & $\mathrm{P}$ & new data \\
\hline Lasiocephala & D. caduca & $\mathrm{P}$ & new data \\
\hline Lasiocephala & D. darwinensis & 0 & new data \\
\hline Lasiocephala & D. derbyensis & $\mathrm{P}$ & new data \\
\hline Lasiocephala & D. dilatatopetiolaris & 0 & new data \\
\hline Lasiocephala & $\begin{array}{l}\text { D. falconeri ( } 2 \text { different accessions } \\
\text { tested) }\end{array}$ & 0 & new data \\
\hline Lasiocephala & D. fulva & M & new data \\
\hline Lasiocephala & D. kenneallyi & $\mathrm{P}$ & new data \\
\hline Lasiocephala & D. lanata (Qld.) & 0 & new data \\
\hline Lasiocephala & D. aff. lanata $(\mathrm{NT})$ & 0 & new data \\
\hline Lasiocephala & D. paradoxa (Arnhem Escarpment) & 0 & new data \\
\hline Lasiocephala & D. aff. paradoxa (swamp form) & 0 & conf. Schlauer et al. 2019a \\
\hline Lasiocephala & D. aff. paradoxa (orange form) & 0 & new data \\
\hline Lasiocephala & D. petiolaris (Q1d.) & 0 & conf. Culham \& Gornall $1994 ?$ \\
\hline Lasiocephala & D. petiolaris $(\mathrm{NT})$ & 0 & conf. Culham \& Gornall $1994 ?$ \\
\hline Ergaleium & D. macrantha (s.str.) & $\mathrm{P}$ & conf. Culham \& Gornall $1994 ?$ \\
\hline Ergaleium & D. moorei & P-trace & new data \\
\hline Ergaleium & D. gracilis (Papua New Guinea) & $\mathrm{P}, \mathrm{M}$-trace & new data \\
\hline Ergaleium & D. gunniana (Tasmania) & P, M-trace & new data \\
\hline Ergaleium & D. hookeri (Tasmania) & P, M-trace & new data \\
\hline Ergaleium & D. lunata (Thailand) & $\mathrm{P}+\mathrm{M}$ & new data \\
\hline Ergaleium & D. auriculata (NSW) & $\mathrm{P}$ & conf. Culham \& Gornall 1994 \\
\hline Ergaleium & D. zigzagia & $\mathrm{P}$ & new data \\
\hline Erythrorhiza & D. aberrans & $\mathrm{P}+\mathrm{M}$ & cf. Schlauer et al. 2019a (only M) \\
\hline Stolonifera & D. stolonifera (s.str.) & 0 & cf. Culham \& Gornall 1994 (P) \\
\hline Arachnopus & D. barrettiorum & M & new data \\
\hline Arachnopus & D. margaritacea & P, M-trace & new data \\
\hline Drosera & D. amazonica (locus classicus) & $\mathrm{M}$ & new data \\
\hline Drosera & D. aff. amazonica (Colombia) & P, M-trace & new data \\
\hline Drosera & D. biflora (Colombia) & $\mathrm{P}$ & new data \\
\hline Drosera & D. biflora $\times$ D. ? (esmeraldae?) & $\mathrm{P}+\mathrm{M}$ & new data \\
\hline Drosera & D. esmeraldae (Venezuela) & M & new data \\
\hline
\end{tabular}




\begin{tabular}{|l|l|l|l|}
\hline \multicolumn{1}{|c|}{ Table 1. Continued } \\
\hline \multicolumn{1}{|c|}{ Section } & \multicolumn{1}{|c|}{ Taxon } & Quinone(s) & \multicolumn{1}{c|}{ Comment } \\
\hline Drosera & $\begin{array}{l}\text { D. intermedia (Gran Sabana, } \\
\text { Venezuela) }\end{array}$ & $\mathrm{P}$ & conf. Culham \& Gornall 1994 \\
\hline Drosera & D. brevifolia (Brazil) & $\mathrm{P}, \mathrm{M}$-trace & cf. Trevisan Ferreira et al. 2004 (P) \\
\hline Ptycnostigma & D. flexicaulis (Zambia) & $\mathrm{P}$ & new data \\
\hline Ptycnostigma & D. madagascariensis (Madagascar) & $\mathrm{M}$ & conf. Culham \& Gornall 1994 \\
\hline Ptycnostigma & D. madagascariensis (Zambia) & $\mathrm{M}$ & conf. Culham \& Gornall 1994 \\
\hline Ptycnostigma & D. pilosa (Zambia) & $\mathrm{M}$ & new data \\
\hline Brasilianae & D. graminifolia (s.str.) & $\mathrm{M}$ & new data \\
\hline Brasilianae & D. magnifica & $\mathrm{M}$ & new data \\
\hline Brasilianae & D. tentaculata & $\mathrm{M}$ & new data \\
\hline
\end{tabular}

\section{Discussion}

After the detection of trace amounts of $\mathbf{P}$ in Drosera banksii (Schlauer et al. 2019a) the (more pronounced) occurrence of the same quinone in four additional species was not entirely unexpected in D. section Lasiocephala. Together with the fact that most other species of this section lack naphthoquinones, our results indicate a close relationship between D. broomensis Lowrie, D. caduca Lowrie, and D. derbyensis Lowrie. All of these are confined to the Kimberley region of northernmost West Australia and are possibly further linked to D. kenneallyi Lowrie, that occurs both in the Kimberley and in the Northern Territory and is morphologically a close relative of $D$. falconeri K.Kondo (endemic to the Darwin region of the Northern Territory, cf. Lowrie 2014), which is apparently devoid of naphthoquinones. The presence of the regio-isomer ramentaceone (M) in D. fulva Planch. (so far known only from the Northern Territory) indicates an isolated position in the section, possibly together with the morphologically very similar and geographically overlapping $D$. brevicornis Lowrie that lacks naphthoquinones.

$\mathbf{P}$ is doubtlessly the main quinone in D. sections Ergaleium DC. and Erythrorhiza Planch. (Culham \& Gornall 1994) and this holds true for the close relatives of $D$. peltata, of which most also contain trace amounts of $\mathbf{M}$, and D. lunata Buch.-Ham. ex DC. (at least in the specimen from Thailand that we investigated) even contains both quinones at comparable concentrations. Our discovery of $\mathbf{P}$ as an additional quinone in D. aberrans (Lowrie \& Carlquist) Lowrie \& Conran, in which an earlier study (Schlauer et al. 2019a) had identified only M, consolidates its position (makes it chemically less "aberrant") in $D$. section Erythrorhiza. In this study we failed to detect $\mathbf{P}$ in D. stolonifera Endl. (in contrast to Culham \& Gornall 1994), but as absence of metabolites does not constitute a reliable feature (especially if there is some deviating evidence), we abstain from drawing taxonomic conclusions from our result.

Once the detection of $\mathbf{M}$ in D. section Arachnopus was a surprise (Schlauer et al. 2017), and it remains less common there than $\mathbf{P}$. It can thus be taken as further proof for the taxonomic significance of quinone patterns that $\mathbf{M}$ is the characteristic isomer in both $D$. barrettiorum and D. hartmeyerorum, that are jointly distinguished from all other relatives by emergences with exceptionally large heads at the leaf bases and that are morphologically similar and geographically overlapping (Lowrie 2014). The recently described species D. margaritacea (Krueger \& Fleischmann 2021) is the first Australian member of $D$. section Arachnopus to produce both quinone isomers (with $\mathbf{M}$ at trace amounts but clearly detectable), a pattern previously identified in this section only in species outside Australia so far ( $D$. indica L. and D. serpens s.1. (D. makinoi Masam.; Schlauer et al. 2019b)). The morphologically similar 
D. finlaysoniana is apparently invariably characterized by formation of the $\mathbf{M}$-precursor dihydroramentaceone while $\mathbf{P}$ is the main quinone with $\mathbf{M}$ remaining below detection (Schlauer et al. 2021).

D. sections Drosera, Ptycnostigma Planch., and Brasilianae Rivadavia, Gonella \& A.Fleischm. constitute the widespread "crown group" of the genus that includes the vast majority of species outside Australia. $\mathbf{M}$ is generally the dominant quinone in all three sections. $\mathbf{P}$ is interestingly found in D. flexicaulis Welw. ex Oliv., which confirms its close relationship with D. affinis Welw. ex Oliv. (cf. Schlauer et al. 2019a). A plant morphologically similar to D. amazonica Rivadavia, A.Fleischm. \& Vicent. clearly deviates from typical specimens, which may indicate the influence of another taxon (introgression?). A plant (containing both $\mathbf{M}$ and $\mathbf{P}$ ) is suspected to represent a hybrid involving $D$. biflora Willd. in Roem. \& Schult. (that contains P). The other parent may be D. esmeraldae (Steyerm.) Maguire \& Wurdack (that has possibly contributed its quinone, M). These examples further demonstrate the utility of quinone patterns, especially in taxa of reticulate evolution, (Schlauer \& Fleischmann 2016) where morphological comparison alone often does not yield unambiguous results.

Acknowledgements: The late Allen Lowrie is thanked with all due respect for his contributions to science and his extensive, educative, and inspiring discussions with both authors that will remain in our memories as a precious treasure to build on. He is further thanked for providing seed material for research, many of which resulted in plants studied in the present work. Additional material was provided by Fernando Rivadavia, Paulo M. Gonella, Kamil Pasek, Robert Gibson, Darren Cullen, Stefan Ippenberger, and Thomas Gronemeyer, who are thanked for their generous donations. Siegfried Hartmeyer and Heiko Rischer are thanked for reviewing and improving the manuscript.

\section{References}

Culham A., and Gornall, R.J. 1994. The taxonomic significance of naphthoquinones in the Droseraceae. Biochem. System. Ecol. 22: 507-515.

Gibson, R., Conn, B.J., and Bruhl, J.J. 2012. Morphological evaluation of the Drosera peltata complex (Droseraceae). Aust. Syst. Bot. 25: 49-80.

Krueger, T., and Fleischmann, A. 2021. A new species of Drosera section Arachnopus (Droseraceae) from the western Kimberley, Australia, and amendments to the range and circumscription of Drosera finlaysoniana. Phytotaxa 501: 56-84.

Lowrie, A. 2014. Carnivorous Plants of Australia: Magnum Opus. Redfern Natural History Productions, Poole.

Salas, M. de. 2018. Drosera gunniana comb. et stat. nov., a species in the Drosera peltata (Droseraceae) complex. Muelleria 36: 97-106.

Schlauer, J., and Fleischmann, A. 2016. Chemical evidence for hybridity in Drosera (Droseraceae). Biochem. Syst. Ecol. 66: 33-36.

Schlauer, J., Hartmeyer, S.R.H., and Hartmeyer, I. 2017. Unexpected discovery of 7-methyljuglone (ramentaceone) in several Australian sundews. Carniv. Pl. Newslett. 46: 20-22.

Schlauer, J., Hartmeyer, S.R.H., Hartmeyer, I., Hennern, H., and Hennern, A. 2019a. New sundew quinone and emergence data. Carniv. P1. Newslett. 48: 6-12.

Schlauer, J., Hartmeyer, S.R.H., and Hartmeyer, I. 2019b. Quinone patterns and identification of Japanese spider leg sundews (Drosera sect. Arachnopus). Carniv. Pl. Newslett. 48: 161-163.

Schlauer, J., Hartmeyer, S.R.H., Hartmeyer, I., Seppänen-Laakso, T., and Rischer, H. 2021. Contrasting dihydronaphthoquinone patterns in closely related Drosera (sundew) species enable taxonomic distinction and identification. Plants (Basel) 10: 1601. https://doi.org/ 10.3390/ plants 10081601

Trevisan Ferreira, D., Andrei, C., Saridakis, H., Faria, T.J., Vinhato, E., Carvalho, K., Daniel, J., Machado, S., Saridakis, D., and Braz-Filho, R. 2004. Antimicrobial activity and chemical investigation of Brazilian Drosera. Mem. Inst. Oswaldo Cruz 7: 753-755. 